This manuscript is contextually identical with the following published paper:

Factors affecting reproductive success in three entomophilous orchid species in Hungary

Anna E. Vojtkó, Judit Sonkoly, Balázs András Lukács, and Attila Molnár V.

Acta Biologica Hungarica 2015 66:2, 231-241

DOI: http://dx.doi.org/10.1556/018.66.2015.2.9

The original published pdf available in this website:

http://www.akademiai.com/doi/abs/10.1556/018.66.2015.2.9

\title{
FACTORS AFFECTING REPRODUCTIVE SUCCESS IN THREE ENTOMOPHILOUS ORCHID SPECIES IN HUNGARY
}

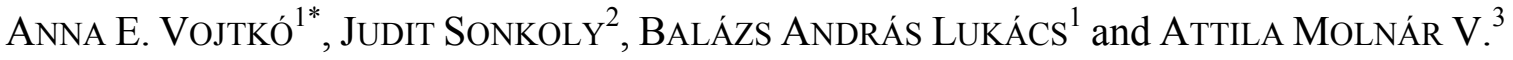 \\ ${ }^{1}$ Department of Tisza Research, Danube Research Institute, MTA Centre for Ecological \\ Research, Debrecen, Hungary \\ ${ }^{2}$ Department of Ecology, Faculty of Science and Technology, University of Debrecen, \\ Debrecen, Hungary \\ ${ }^{3}$ Department of Botany, Faculty of Science and Technology, University of Debrecen, \\ Debrecen, Hungary \\ *corresponding author; e-mail: vojtko.anna@okologia.mta.hu
}

\begin{abstract}
The reproductive success of orchids is traditionally estimated by determining the fruit-set of individuals. Here, we investigated both the fruit and the seed production of three orchid species and the factors that may affect individual fruit-set, like pollination strategy, individual traits or the annual amount of precipitation. The species (Dactylorhiza sambucina (L.) Soó, Dactylorhiza majalis (Rchb.) P. F. Hunt \& Summerhayes and Platanthera bifolia (L.) L. C. M. Richard) were studied in three consecutive years (2010-2012) in the Bükk Mountains, Hungary. All three species were proved to be non-autogamous by a bagging experiment. Data analyses showed significant differences between seed numbers but not between fruit-sets of species. There was no statistical difference in individual reproductive success between wet and dry years, however, the effect of the annual amount of precipitation is significant on the population level. Comparison of published fruit-set data revealed accordance with our results in $P$. bifolia, but not in D. sambucina and D. majalis. We assume that the surprisingly high fruit-set values of the two Dactylorhiza species may be due to the fact that the pollination crisis reported from Western European countries may not be an actual problem in the Bükk Mountains, Hungary.
\end{abstract}

Key words: Dactylorhiza majalis - Dactylorhiza sambucina - fruit-set - Platanthera bifolia - pollination crisis

Running title: Reproductive success of three orchid species 


\section{Introduction}

Orchids are commonly known as a threatened group of plants due to several species being rare and endangered and recently showing strong decrease in their distribution areas [15]. The success of orchids in a habitat depends on several factors, but it is mostly affected by their reproductive success. Due to their conservation value the investigation of their reproductive success is quite a relevant topic today. It is proved that reproductive success is predicted by individual traits like pollination mode (rewarding, non-rewarding, autogamous), plant height, etc. and also predicted by community and environmental features like population size and annual precipitation.

The generally used method of quantifying the reproductive success of orchids is determining fruit-set (the proportion of flowers which developed into fruits) [28].

Although, many studies have discussed reproductive success of orchids by giving fruit-set data (e. g. [20]), quite a few attempted to deal with seed numbers [27]. Providing seed numbers per fruit or even per specimen may give further information on reproductive success, as the large number of seeds produced in every fruit compensates for low effectiveness of deceptive pollination and may ensure the persistence of the populations [10]. Extremely high seed number of higher quality seeds together with the energy-saving strategy of non-rewarding orchids may explain the success of this strategy.

In previous studies (e.g. [28, 4, 5]) pollination mode was proved to be the main predictor of reproductive success. Most orchid species have low reproductive success, as far as fruit-set is concerned [2]; especially non-rewarding species are not frequently visited [11]. The mean fruit-set of rewarding orchid species in Europe is $63.1 \%$, while that of their deceptive relatives were found to be only $27.7 \%$ [28].

There is little and contradictory evidence available on the effects of individual traits and population characteristics on the reproductive success of orchids (for a review see [36]). Inflorescence size (number of flowers produced in the flowering season) may affect fruit-set, as plants with many flowers appear to be more attractive to pollinators [16]. Floral display (number of flowers open at the same time) is found to be an important factor especially concerning non-rewarding species [8]. Brys et al [6] proved that in Listera ovata (Neottia ovata) a larger inflorescence is more likely to be visited by pollinators and have its pollinaria removed than a smaller one. Larger floral displays were found to attract more pollinators in a given unit of time, and receive longer visitations as well [26, 30]. The bigger the inflorescence, the longer the flowering time is [10], which results in higher number of visitations and higher fruit-set [25].

Plant height appears to be less widely studied than other traits, however, pollinators are known to forage at a particular height [29]. Therefore, taller specimens may achieve greater reproductive success than shorter ones, independently of the size of floral display [19].

A larger population, with a high number of flowering plants, usually affects individual reproductive success positively [15], as fruit-set was proved to be significantly higher in populations with more flowering specimens [36]. In contrast to this, other populations with a high number of flowering specimens were found to have reduced reproductive success (i.e. Lapeirousia oreogena - [18], Drakaea spp. - [32]). Pollinators spend longer time periods and visit a higher number of flowers in larger populations [21, 22, 33], however, it may be disadvantageous where pollinators are scarce [6]. Fruit-set significantly positively correlates with local population density in the rewarding Listera ovata according to Brys et al. [6] Deceptive orchids, however, would not be successful in populations where plants are in either very dense or sparse patches [34]. Specimens in smaller, sparse populations often have lower 
reproductive success than in larger ones [23, 3], and small populations are often exposed to increased geitonogamous self-pollination [17].

Reproductive success of orchids has an undoubted conservational importance, as several species are rare and endangered and recently showing strong decrease in their distribution areas [15]. Therefore the investigation of the reproductive success of orchid species is quite a relevant topic today.

According to the above mentioned we can see that quantifying reproductive success is complicated because these factors can conversely affect each other.

In this study our main research question aimed at identifying which factors actually determine the reproductive success of orchid species. For this reason we investigated three orchid species and those factors that may affect their individual fruit-set, like pollination strategy, individual traits or the annual amount of precipitation. This only makes sense if we exclude the possibility of facultative autogamy among the studied species. For the main question we set up four hypotheses:

i) All three studied species are entomophilous (non-autogamous) taxa; their fruits are products of pollination events by insects. ii) Pollination mode may predict fruit-set of orchid species. iii) Fruit-set is dependent on individual traits like plant height, inflorescence length and size and population density. iv) Reproductive success is different in wet and dry years.

\section{Materials and Methods}

Field study

Field studies were carried out in populations of Dactylorhiza majalis (Rchb.) P. F. Hunt \& Summerhayes 1965, Dactylorhiza sambucina (L.) Soó 1962 and Platanthera bifolia (L.) L. C. M. Richard in the Bükk Mountains (Northern Hungary) between 2010 and 2012. The biological characteristics of these species and locations are found in Table 1. All three species were sampled in a 'wet' (2010) and a 'dry' (2011 or 2012) year (Table 2).

\section{Table 1}

Characteristics of the studied taxa. Pollinators are provided according to Claessens and Kleynen [9].

\begin{tabular}{|c|c|c|c|c|}
\hline Species & $\begin{array}{l}\text { Pollination } \\
\text { mode }\end{array}$ & Pollinators & Location & $\begin{array}{l}\text { Study } \\
\text { years }\end{array}$ \\
\hline $\begin{array}{l}\text { Dactylorhiza } \\
\text { sambucina }\end{array}$ & $\begin{array}{l}\text { Food } \\
\text { deceptive }\end{array}$ & $\begin{array}{l}\text { Hymenoptera: } \\
\text { Bombus (9 species), } \\
\text { Apis mellifera, } \\
\text { Andraena nigroaenea }\end{array}$ & $\begin{array}{l}\text { Felsőtárkány: } \\
\text { Hereg-rét } \quad(\mathrm{N} \\
48.05^{\circ} ; \\
\left.\text { E } 20.48^{\circ}\right)\end{array}$ & $\begin{array}{l}2010, \\
2012\end{array}$ \\
\hline $\begin{array}{l}\text { Dactylorhiza } \\
\text { majalis }\end{array}$ & $\begin{array}{l}\text { Food } \\
\text { deceptive }\end{array}$ & $\begin{array}{l}\text { Hymenoptera: } \\
\text { Bombus (7 species); } \\
\text { Coleoptera (1 } \text { species) }\end{array}$ & $\begin{array}{l}\text { Miskolc: } \\
\text { Létrástető } \\
\left(\mathrm{N} 48.10^{\circ} \text {; }\right. \\
\left.\text { E } 20.58^{\circ}\right)\end{array}$ & $\begin{array}{l}2010, \\
2011\end{array}$ \\
\hline Platanthera bifolia & $\begin{array}{l}\text { Nectar } \\
\text { rewarding }\end{array}$ & $\begin{array}{l}\text { Lepidoptera } \\
\text { (13 genera, } 20 \text { species })\end{array}$ & 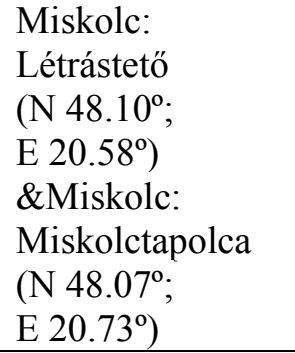 & $\begin{array}{l}2010, \\
2011\end{array}$ \\
\hline
\end{tabular}


Table 2

Meteorological characteristics of study years observed in Miskolc $\left(\mathrm{N} 48.10^{\circ}, \mathrm{E} 20.77^{\circ}\right)$ according to the Hungarian Central Statistical Office [14].

\begin{tabular}{ccccc}
\hline Year & $\begin{array}{c}\text { Average annual } \\
\text { temperature }\left({ }^{\circ} \mathrm{C}\right)\end{array}$ & $\begin{array}{c}\text { Number of annual } \\
\text { sunny hours }\end{array}$ & $\begin{array}{c}\text { Number of annual } \\
\text { precipitation days }\end{array}$ & $\begin{array}{c}\text { Annual precipitation } \\
(\mathrm{mm})\end{array}$ \\
\hline 010 & 9.7 & 1893 & 185 & 1166 \\
011 & 10.4 & 2289 & 109 & 484 \\
012 & 10.9 & 2297 & 113 & 521 \\
\hline
\end{tabular}

All populations were surveyed twice each year. (1) During anthesis the number of flowering specimens was estimated in the population (hereafter: 'population size'). Individual characteristics: height of the flowering stem (hereafter: 'height') and inflorescence length were measured and the number of flowers (hereafter: 'inflorescence size') was recorded on randomly selected, individually marked specimens. Population density was measured by providing the distances of the 5 closest flowering specimens from the marked specimen. (2) During fruit ripening (4-6 weeks after flowering) the number of fruits was recorded individually and 1 half-mature (intact) capsule was collected from three regions (upper, middle and lower) of the infrutescence.

To exclude the possibility of facultative autogamy we tested the ability for autogamy on the studied species. Before anthesis 5-5 individuals of all three species were bagged with a fine net, in order to prevent pollination by insects.

\section{Quantifying reproductive success}

Individual fruit-set data were generated as quotient of the number of fruits and the number of flowers. Seed numbers per fruit ('capsular seed number') were determined under light microscope following the methodology of Sonkoly et al. [35]. Seed numbers per specimens were given by the mean of the three determined capsular seed numbers of a certain individual multiplied by the number of matured fruits of the same individual. Seed numbers per populations were calculated by the mean seed number per specimen multiplied by the estimated number of flowering individuals of the population.

\section{Data analyses}

$\mathrm{R}$ statistical environment ( $\mathrm{R}$ Development Core Team 2010) was used for all statistical analyses. Normality was tested using Shapiro-Wilk Normality Test. Paired difference tests (Welch Two Sample t-test and Wilcoxon rank sum test) were used to test whether there is a significant difference between the fruit-sets, capsular seed numbers and seed numbers per specimens of species pairs, and between the fruit-set, capsular seed number and seed numbers per specimens of each species in different years. Correlation tests (Spearman's rank correlation) were used to search for correlations between fruit-set and individual traits (height, inflorescence length, inflorescence size and population density) and between pairs of certain individual traits (height and inflorescence length; inflorescence length and inflorescence size; height and inflorescence size; inflorescence size and number of fruits). In order to get the proper direction of the correlation between fruit set and population density, the distances of the five nearest individuals were summed and multiplied by -1 . 


\section{Results}

None of the bagged individuals produced any fruits in any of the species.

Altogether 258 capsules of 106 specimens were examined, and fruit-set data of 161 individuals were recorded during the studied years (Table 3). We found that capsular seed numbers and seed numbers per specimens significantly differed between $D$. majalis and $D$. sambucina and between P. bifolia and D. sambucina. P. bifolia and D. majalis significantly differed in their capsular seed numbers. Fruit-sets of the three species did not differ significantly (Table 4).

Table 3

Characteristics of the studied populations

\begin{tabular}{lllllll}
\hline Species & Year & FS \pm SE & CapSN \pm SE & SN/Sp \pm SE & Pop & SN/Pop \\
\hline $\begin{array}{l}\text { Dactylorhiza } \\
\text { sambucina }\end{array}$ & 2010 & $\begin{array}{l}0.527 \pm 0.052 \\
(\mathrm{n}=31)\end{array}$ & $\begin{array}{l}2735 \pm 188 \\
(\mathrm{n}=32)\end{array}$ & $\begin{array}{l}14621 \pm 3093 \\
(\mathrm{n}=16)\end{array}$ & $\approx 1000$ & 14621000 \\
& 2012 & $\begin{array}{l}0.535 \pm 0.038 \\
(\mathrm{n}=45)\end{array}$ & $\begin{array}{l}3426 \pm 304 \\
(\mathrm{n}=34)\end{array}$ & $\begin{array}{l}21890 \pm 4674 \\
(\mathrm{n}=11)\end{array}$ & $\approx 500$ & 10945000 \\
\hline $\begin{array}{l}\text { Dactylorhiza } \\
\text { majalis }\end{array}$ & 2010 & $\begin{array}{l}0.618 \pm 0.052 \\
(\mathrm{n}=18)\end{array}$ & $\begin{array}{l}10029 \pm 391 \\
(\mathrm{n}=51)\end{array}$ & $\begin{array}{l}121929 \pm 16897 \\
(\mathrm{n}=18)\end{array}$ & $\approx 100$ & 12192900 \\
& 2011 & $\begin{array}{l}0.538 \pm 0.049 \\
(\mathrm{n}=24)\end{array}$ & $\begin{array}{l}7332 \pm 315 \\
(\mathrm{n}=32)\end{array}$ & $\begin{array}{l}82596 \pm 12838 \\
(\mathrm{n}=19)\end{array}$ & $\approx 50$ & 4129800 \\
\hline $\begin{array}{l}\text { Platanthera } \\
\text { bifolia }\end{array}$ & 2010 & $\begin{array}{l}0.624 \pm 0.064 \\
(\mathrm{n}=24)\end{array}$ & $\begin{array}{l}6440 \pm 387 \\
(\mathrm{n}=74)\end{array}$ & $\begin{array}{l}111492 \pm 16109 \\
(\mathrm{n}=23)\end{array}$ & $\approx 150$ & 16723800 \\
& 2011 & $\begin{array}{l}0.534 \pm 0.047 \\
(\mathrm{n}=34)\end{array}$ & $\begin{array}{l}6262 \pm 524 \\
(\mathrm{n}=35)\end{array}$ & $\begin{array}{l}82505 \pm 13616 \\
(\mathrm{n}=19)\end{array}$ & $\approx 70$ & 5775350 \\
\hline
\end{tabular}

FS: mean fruit-set. CapSN: mean capsular seed number, SN/Sp: mean seed number per specimen, Pop: estimated population size, SN/Pop: estimated seed number per population

Certain individual traits were found to correlate with fruit-set in two of the studied species. In D. sambucina no correlation was found between fruit-set and the particular traits. The fruit-set of $D$. majalis correlated with height, inflorescence length and population density, while the fruit-set of $P$. bifolia only correlated with inflorescence size (Table 5).

Table 4

Pairwise comparison of three studied reproductive characters

(Welch Two Sample t-test and Wilcoxon rank sum test).

\begin{tabular}{lll}
\hline D. majalis - D. sambucina & fruit-set & $\mathrm{p}=0.448$ \\
\cline { 2 - 3 } & capsular seed number & $\mathrm{p}<0.0001$ \\
\cline { 2 - 3 } & seed numbers per specimens & $\mathrm{p}<0.0001$ \\
\hline D. majalis - P. bifolia & fruit-set & $\mathrm{p}=0.9522$ \\
\cline { 2 - 3 } & capsular seed number & $\mathrm{p}=0.03892$ \\
\cline { 2 - 3 } & seed numbers per specimens & $\mathrm{p}=0.8284$ \\
\hline P. bifolia - D. sambucina & fruit-set & $\mathrm{p}=0.1551$ \\
\cline { 2 - 3 } & capsular seed number & $\mathrm{p}<0.0001$ \\
\cline { 2 - 3 } & seed numbers per specimens & $\mathrm{p}<0.0001$ \\
\hline
\end{tabular}


Table 5

Correlations of studied traits with fruit-set (Spearman's rank correlation).

\begin{tabular}{lllll}
\hline Species & $\begin{array}{l}\text { Plant height } \\
(\mathrm{cm})\end{array}$ & $\begin{array}{l}\text { Inflorescence } \\
\text { length }(\mathrm{cm})\end{array}$ & $\begin{array}{l}\text { Nr. of flowers/ } \\
\text { inflorescence }\end{array}$ & $\begin{array}{l}\text { Population density } \\
(-\mathrm{cm})\end{array}$ \\
\hline D. sambucina & $\mathrm{p}=0.2213$ & $\mathrm{p}=0.2006$ & $\mathrm{p}=0.06556$ & $\mathrm{p}=0.391$ \\
& - & - & - & - \\
D. majalis & $\mathrm{p}=0.02698$ & $\mathrm{p}=0.0045$ & $\mathrm{p}=0.3299$ & $\mathrm{p}=0.04144$ \\
& $\mathrm{r}=0.3412$ & $\mathrm{r}=0.4297$ & - & $\mathrm{r}=0.3160$ \\
P. bifolia & $\mathrm{p}=0.9431$ & $\mathrm{p}=0.06105$ & $\mathrm{p}=0.01007$ & $\mathrm{p}=0.7431$ \\
& - & - & $\mathrm{r}=0.3928$ & - \\
\hline
\end{tabular}

We found significant correlation between plant height and inflorescence length in all species (D. sambucina: $\mathrm{r}=0.6511188 \mathrm{p}<0.001$, D. majalis: $\mathrm{r}=0.6451277, \mathrm{p}<0.001$ and $P$. bifolia: $\mathrm{r}=0.6960524, \mathrm{p}<0.001)$. Significant positive correlation was revealed between height and inflorescence size $(\mathrm{R}=0.549755, \mathrm{p}<0.001)$ and inflorescence length and inflorescence size $(\mathrm{R}=0.7774081, \mathrm{p}<0.001)$ of $D$. sambucina. Positive correlation was found between the number of flowers and the number of fruits in all the three species (D. sambucina: $\mathrm{r}=0.2544691, \mathrm{p}=0.02 ;$ D. majalis: $\mathrm{r}=0.59829, \mathrm{p}<0.001 ;$ P. bifolia: $\mathrm{r}=0.7610293, \mathrm{p}<0.001)$.

We found inconsistent patterns in the correlation of precipitation and fruit-sets, capsular seed numbers and seed numbers per specimens. These traits did not always show decline in dry years $(2011,2012)$ compared to a wet year $(2010)$. We found insignificant correlations between these traits and precipitation in case of D. sambucina and P. bifolia. Merely the capsular seed numbers of D. majalis differed significantly between 2010 and 2011 $(\mathrm{p}<0.001)$. When considering the number of flowering individuals of the populations as well, which appears to have dropped to approximately half of the previous number at every location, a substantial decline can be observed in seed numbers per populations (see Table 3 ).

Table 6

Comparison of the fruit-set data of the studied Hungarian populations with published international data.

\begin{tabular}{llll}
\hline & D. sambucina & D. majalis & P. bifolia \\
\hline Present study & $\begin{array}{l}\text { 0.539 (2 years, } \\
1 \text { population) }\end{array}$ & $\begin{array}{l}\text { 0.572 (2 years, } \\
1 \text { population })\end{array}$ & $\begin{array}{l}0.602(2 \text { years, } \\
2 \text { populations })\end{array}$ \\
\hline Claessens and & $0.209(16$ years, & $0.353(11$ years, & $0.637(13$ years, \\
Kleynen [9] & 26 populations $)$ & 16 populations $)$ & 12 populations $)$ \\
\hline & $\mathrm{p}<0.001$ & $\mathrm{p}=0.001457$ & $\mathrm{p}=0.5686$ \\
& Wilcoxon test & Wilcoxon test & Wilcoxon test \\
\hline
\end{tabular}

Fruit-set values were surprisingly high in the two deceptive species, but our fruit-set data followed the European trend according to Claessens and Kleynen (2011). Among the examined species $P$. bifolia had the highest, D. sambucina the lowest and D. majalis the middle values. In case of the two deceptive Dactylorhiza species fruit-set data extracted from international literature sources were found to be significantly lower than our detected values. Fruit-set of the nectar rewarding P. bifolia did not differ significantly (Table 6). 


\section{Discussion}

We revealed that all the studied species are entomophilous. As none of the bagged individuals produced any fruits, we can exclude the possibility of facultative autogamy in all the studied species, which is necessary for elucidating our study question. This result is in accordance with previous studies of Pellegrino et al. [31] on D. sambucina but in contrast with that of Brzosko [7], where four out of five bagged Platanthera bifolia individuals produced fruits. We assume that these results may be inconsistent due to the different bags used. According to our observations, a smaller mesh size would be more appropriate in orchids pollinated by Lepidoptera species, as our preliminary studies on the nectar rewarding Gymnadenia odoratissima (L.) Rich. showed that butterflies are able to reach flowers through the net with their long and thin proboscis.

We found that pollination mode did not affect the fruit-set of the studied species as it was hypothesized. We revealed that the reproductive success of the studied deceptive species neared to that of the nectar rewarding species.

According to Sabat and Ackerman [34] the effect of floral characteristics on reproductive success can be different regarding pollination modes. Insects pollinating nectar rewarding species often visit many flowers on the same individual causing higher fruit-set for those having larger inflorescences. In non-rewarding species pollinators learn to avoid deceptive flowers after a few visits, hence, large inflorescences are not beneficial there. Population density has a similar impact on individual fruit-set [34]. In a dense rewarding population fruit-set tends to be higher, but in deceptive populations due to negative reinforcement [1] a dense population is not necessarily more successful [6].

We found partly contradictory results to our third hypotheses. No correlation was found between the fruit-set of D. sambucina and the investigated traits. This corroborates with the results of Pellegrino et al. [31], who found that reproductive success was independent from plant density and inflorescene size as well.

Furthermore, the positive correlation found between the fruit-set of D. majalis and traits taking part in pollinator attraction (height, inflorescence length, population density) was in contrast with the findings of Hansen and Olesen [13], as they discussed fruit-set and population size to be uncorrelated. The positive correlation may be the consequence of the assumption that the number of naïve pollinators visiting deceptive flowers (flowers of $D$. majalis) is more than sufficient in the Bükk Mountains in Hungary.

Several studies proved inflorescence size to be influential regarding reproductive success, as plants with larger inflorescences seems to produce (absolutely) more fruits e. g. [32]. Correlation between the number of flowers and the number of fruits was found to be positively significant in all species. In contrast, correlation between the number of flowers and reproductive success (fruit-set) is not evident. Only the fruit-set of $P$. bifolia showed relatedness to inflorescence size as Maad [24] observed previously as well. Pollinators of the nectar rewarding $P$. bifolia may rather visit more flowers of a larger inflorescence at the same time and save energy, as it may be less time-consuming.

The correlation between plant height and inflorescence length may exist due to the fitness of the certain individual as larger ones are able to produce larger inflorescences. Those are more frequently visited by pollinators, being more attractive.

Differences between reproductive success of the species in wet and dry years were not significant. We found significant decrease of capsular seed number only in D. majalis between the dry and wet years. A possible explanation of this result is that this species has the highest moisture indicator value [12] among the three (D. majalis $\mathrm{W}$-value $=8 ; D$. sambucina 
$\mathrm{W}$-value $=4 ; P$. bifolia $\mathrm{W}$-value $\approx 5$ ). Therefore, it may have been affected more severely by the smaller amount of precipitation in 2011.

No reduction was observed in the reproductive success of $D$. sambucina and P. bifolia between the years, only if we weighted the results with the estimated number of flowering individuals of the populations. Specimens flowering in dry years did not have a reduced reproductive success, but only half of the populations flowered in 2011 and 2012 compared to 2010. In D. sambucina the seed number of the population decreased by one third, while in $D$. majalis and $P$. bifolia it decreased by two thirds of the 2010 value.

Due to the surprisingly high fruit-set values of the two Dactylorhiza species, we compared our results to other literature data [9] to see general trends in Europe. Pair tests showed substantial differences in the fruit-set of the two deceptive species, as our values were higher in both cases. We would like to note that these results must be handled cautiously, as Claessens and Kleynen [9] published data of a high number of populations from a broad period of time, while our results concerned only a few populations from two consecutive years. Nevertheless, we assume that the pollination crisis reported from Britain and The Netherlands by Biesmeijer et al. [3] may not be an actual problem in the Bükk Mountains in Hungary. They describe connected local extinctions of interacting plant and insect species. These coincident declines may be due to the preliminary decline of insects followed by that of plants or the plants preceding the loss of the linked pollinators. It also seems possible that this tandem decline is a response to some other environmental factor [3]. As the crisis may affect mainly species interacting with relatively few pollinators - like highly specialized deceptive orchids - the most substantial differences were found in the two Dactylorhiza species in the present study.

\section{Acknowledgements}

The authors are grateful to anonymous reviewers for their constructive and helpful comments on the earlier version of the paper. This research was supported by the European Union and the State of Hungary, co-financed by the European Social Fund in the framework of TÁMOP4.2.4.A/2-11/1-2012-0001 'National Excellence Program'. Instrumental and infrastructural support of OTKA K108992 Grant is also highly appreciated.

\section{References}

1. Ackerman JD (1989) Limitations to sexual reproduction in Encyclia krugii (Orchidaceae). Syst Bot 14: 101-109

2. Ackerman JD, Zimmerman J (1994) Bottlenecks in the life histories of orchids: resources, pollination, population structure, and seedling establishment. In Pridgeon AM (ed) Proceedings of the 14th World Orchid Conference. Edinburgh, pp 138-147

3. Biesmeijer JC, Roberts SPM, Reemer M, Ohlemüller R, Edwards M, Peeters T, Schaffers AP, Potts SG, Kleukers R, Thomas CD, Settele J, Kunin WE (2006) Parallel declines in pollinators and insect-pollinated plants in Britain and the Netherlands. Science 313: 351354

4. Biró É, Bódis J, Nagy T, Tökölyi J, Molnár V A (2015): Honeybee (Apis mellifera) mediated increased reproductive success of a rare deceptive orchid. Applied Ecology and Environmental Research 13: 181-192

5. Bódis J \& Molnár E (2009) Long-term monitoring of Himantoglossum adriaticum H. Baumann population in Keszthely Hills, Hungary. Natura Somogyiensis 15: 27-40 
6. Brys R, Jacquemyn H, Hermy M (2008) Pollination efficiency and reproductive patterns in relation to local plant density, population size, and floral display in the rewarding Listera ovata (Orchidaceae). Bot J Linn Soc 157: 713-721

7. Brzosko E (2003) The dynamics of island populations of Platanthera bifolia in the Biebrza National Park (NE Poland). Ann Bot Fenn 40: 243-253

8. Calvo LN (1990) Inflorescence size and fruit distribution among individuals in three orchid species. Am J Bot 77: 1378-1381

9. Claessens J, Kleynen J (2011) The Flower of the European Orchid. Form and function. Jean Claessens and Jacques Kleynen.

10. Cole FR, Firmage DH (1984) The floral ecology of Platanthera blephariglottis. Am J Bot 71: 700-710

11. Dafni A, Ivri Y (1979) Pollination ecology of, and hybridisation between Orchis coriophora L. and O. collina Sol. ex Russ. (Orchidaceae) in Israel. New Phytol 83: 181187

12. Ellenberg H (1974) Indicator values of vascular plants in central Europe. Scripta Geobotanica 9: 1-97

13. Hansen I, Olensen JM (1999) Comparison of reproductive success in two orchids: the nectarless Dactylorhiza majalis s.s. and the nectar-producing Gymnadenia conopsea s.1. Nordic J Bot 19: 665-671.

14. Hungarian Central Statistical Office (2013) Main data of the meteorological observation stations. http://www.ksh.hu/docs/eng/xstadat/xstadat_annual/i_met002b.html [accessed 19.09.2013]

15. Jacquemyn H, Brys R, Hermy M, Willems JH (2005) Does nectar reward affect rarity and extinction probabilities of orchid species? An assessment using historical records from Belgium and the Netherlands. Biol Conserv 121: 257-263

16. Jacquemyn H, Brys R, Honnay N, Hermy M (2008) Effects of coppicing on demographic structure, fruit and seed set in Orchis mascula. Basic Appl Ecol 9: 392-400

17. Johnson SD, Torninger E, Ågren J (2009) Relationships between population size and pollen fates in a moth-pollinated orchid. Biol Letters 5: 282-285

18. Johnson SD, Hollens M, Kuhlmann M (2012) Competition versus facilitation: conspecific effects on pollinator visitation and seed set in the iris Lapeirousia oreogena. Oikos 121: 545-550

19. Johnston MO (1991) Natural selection on floral traits in two species of lobelia with different pollinators. Evolution 45: 1468-1479

20. Kindlmann P, Jersáková J (2006) Effect of floral display on reproductive success in terrestrial orchids. Folia Geobot 41: 47-60

21. Klinkhamer PGL, de Jong TJ, de Bruyn GL (1989) Plant size and pollinator visitation in Cynoglossum officinale. Oikos 54: 201-204

22. Klinkhamer PGL, de Jong TJ (1990) Effects of plant size, plant density and sex differential nectar reward on pollinator visitation in the protandrous Echium vulgare (Boraginaceae). Oikos 57: 399-405

23. Lamont BB, Klinkhamer PGL, Witkowski ETF (1993) Population fragmentation may reduce fertility to zero in Banksia goodii: a demonstration of the Allee effect. Oecologia 94: $446-450$

24. Maad J (2000) Phenotypic selection in hawkmoth-pollinated Platanthera bifolia: Targets and fitness surfaces. Evolution 54: 112-123.

25. Mattila N, Kuitunen MT (2000) Nutrient versus pollination limitation in Platanthera bifolia and Dactylorhiza incarnata (Orchidaceae). Oikos 89: 360-366 
26. Mitchell RJ (1994) Effects of floral traits, pollinator visitation, and plant size on Ipomopsis aggregata fruit production. Am Nat 143: 870-889

27. Nazarov VV (1998) Samen produktivität europäischer Orchideen. I. Methoden zur Bestimmung der Samenzahl. Jour Eur Orch 30: 591-602

28. Neiland MRM, Wilcock CC (1998) Fruit set, nectar reward, and rarity in the Orchidaceae. Am J Bot 85: 1657-1671

29. O'Connell LM, Johnston MO (1998) Male and female pollination success in a deceptive orchid, a selection study. Ecology 79: 1246-1260

30. Ohashi K, Yahara T (1998) Effects of variation in flower number on pollinator visits in Cirsium purpuratum (Asteraceae). Am J Bot 85: 219-224

31. Pellegrino G, Caimi D, Noce ME, Musacchio A (2005) Effects of local density and flower colour polymorphism on pollination and reproduction in the rewardless orchid Dactylorhiza sambucina (L.) Soó. Plant Syst Evol 251: 119-129.

32. Phillips RD, Peakall R, Hutchinson MF, Linde CC, Xu T, Dixon KW, Hopper SD (2014) Specialized ecological interactions and plant species rarity: The role of pollinators and mycorrhizal fungi across multiple spatial scales. Biol Cons 169: 285-295

33. Robertson AW, Macnair MR (1995) The effects of floral display size on pollinator service to individual flowers of Myosotis and Mimulus. Oikos 72: 106-114

34. Sabat AM, Ackerman JD (1996) Fruit set in a deceptive orchid: the effect of flowering phenology, display size, and local floral abundance. Am J Bot 83: 1181-1186

35. Sonkoly J, E. Vojtkó A, Török P, Illyés Z, Sramkó G, Tökölyi J., Molnár V.A (2015) Higher seed number compensates for lower fruit-set in deceptive orchids. $J$ Ecol (submitted)

36. Tremblay RL, Ackerman JD, Zimmerman JK, Calvo RN (2005) Variation in sexual reproduction in orchids and its evolutionary consequences: a spasmodic journey to diversification. Biol J Linn Soc 84: 1-54 